\title{
Control of sulphide during anaerobic treatment of S-containing wastewaters by adding limited amounts of oxygen or nitrate
}

\author{
Dores G. Cirne - Frank P. van der Zee • \\ Maria Fernandez-Polanco $\cdot$ Fernando Fernandez-Polanco
}

Published online: 1 February 2008

(C) Springer Science+Business Media B.V. 2008

\begin{abstract}
Sulphide generated during anaerobic treatment of S-containing wastewaters represents an environmental problem. Adding limited amounts of oxygen or nitrate (or nitrite) to biologically (or chemically) oxidise sulphide forms a simple processlevel strategy to control this problem. This short review evaluates the feasibility and limitations of this strategy on the basis of the results of bioreactor studies.
\end{abstract}

D. G. Cirne - M. Fernandez-Polanco •

F. Fernandez-Polanco

Department of Chemical Engineering and Environmental Technology, Faculty of Sciences, University of

Valladolid, Paseo Prado de la Magdalena s/n, 47011

Valladolid, Spain

M. Fernandez-Polanco

e-mail: maria@iq.uva.es

F. Fernandez-Polanco

e-mail: ffp@iq.uva.es

Present Address:

D. G. Cirne ( $₫)$

Advanced Water Management Centre, The University

of Queensland, Brisbane, QLD 4072, Australia

e-mail: dcirne@uq.edu.au

F. P. van der Zee

IBB-Institute for Biotechnology and Bioengineering, Centre of Biological Engineering, University of Minho, Campus de Gualtar, 4710-057 Braga, Portugal

e-mail: frankvdz@deb.uminho.pt
Keywords Anaerobic treatment · Biogas $\cdot$ Control · Inhibition $\cdot$ Micro-aerobic $\cdot$ Nitrate $\cdot$ Sulphate $\cdot$ Sulphide

\section{Introduction}

Wastewaters containing organic matter and sulphate are generated by many industrial processes that use sulphuric acid (e.g. food and fermentation industry), or sulphate-containing feed stocks (e.g. sea food processing industry). Also the use of less oxidised sulphurous compounds in industrial processes such as sulphide (tanneries, Kraft pulping), sulphite (sulphite pulping), thiosulphate (processing of photographs) or dithionite (pulp bleaching), contributes to the Scontent of wastewaters. Besides these organic wastewaters, there are also sulphate-containing effluents with barely any organic matter. These are generated during leaching of sulphur-containing wastes (mine spoils, landfills) or during scrubbing of sulphur containing off-gases (Lens et al. 1998). In addition, municipal residues rich in sulphate, as well as the sludge generated in municipal wastewater treatment plants, represent sources of sulphur compounds.

During anaerobic treatment of sulphate-containing wastewaters, the presence of sulphate will increase the intricacy of the biodegradation pathways involved. Acidogens, and methanogens will compete with sulphate-reducing bacteria (SRB) for the available 
substrates (organic compounds and hydrogen) (Fig. 1). The outcome of this competition is important as it will determine to which extent sulphide and methane, the main end products of the anaerobic biodegradation process will be produced. In general, interspecies hydrogen will be oxidised by SRB rather than by hydrogenotrophic methanogens, while syntrophic substrates such as propionate and butyrate may be preferentially oxidised to acetate by acetogenic bacteria. The competition between SRB and methanogens for acetate appears to be much more complex, influenced by a large variety of factors (Lens et al. 1998).

Sulphate itself does not pose a threat to the environment as sulphate is a chemically inert, non-volatile and non-toxic compound (Shin et al. 1995). However, the anaerobic reduction of sulphate to sulphide by SRB may have undesirable and/or detrimental effects:

(a) sulphide is inhibitory towards microorganisms. Hydrogen sulphide may interfere with the assimilatory metabolism of sulphur, and it may affect the intracellular $\mathrm{pH}$ (Oude Elferink et al. 1994). In anaerobic systems, methanogens and syntrophic propionate degrading bacteria are generally the most sensitive organisms to sulphide inhibition (Hulshoff Pol et al. 1998). The median inhibition concentration $\left(\mathrm{IC}_{50}\right)$ values reported in literature for methanogenic activity generally range between 30 and $250 \mathrm{mg}$ $\mathrm{S}^{-1}$ (Lens et al. 1998). Depending on the $\mathrm{pH}$ and the sludge structure, the extent of sulphide inhibition may correlate with the free sulphide concentration (granular sludge at $\mathrm{pH}<7$ and suspended sludge) or rather with the total sulphide concentration (granular sludge at $\mathrm{pH}$ >7) (Koster et al. 1986; Visser et al. 1996). Immobilised biofilm reactors may tolerate much higher sulphide levels, presumably due to mass transfer limitation (Lens et al. 1998). The sulphide generated during the anaerobic treatment
Fig. 1 Scheme of the anaerobic degradation pathway of organic material and possible interactions of organic substrate and hydrogen with sulphate, oxygen and nitrate (or nitrite)

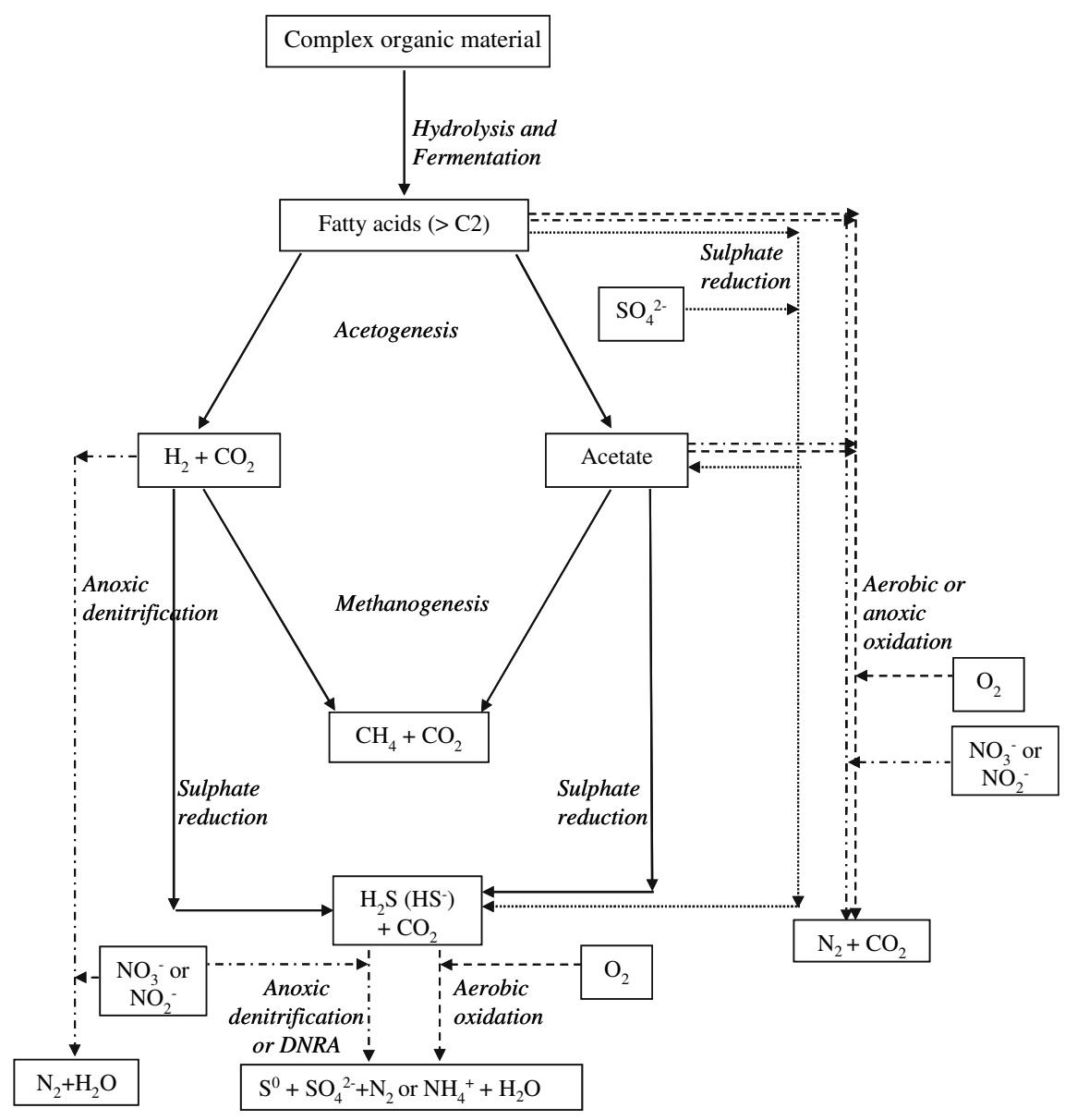


Table 1 Treatment requirements for biogas utilization (adapted from Noyola et al. 2006)

\begin{tabular}{lccc}
\hline Application & $\begin{array}{l}\text { Removal } \\
\text { of } \mathrm{H}_{2} \mathrm{O}\end{array}$ & $\begin{array}{l}\text { Removal } \\
\text { of } \mathrm{CO}_{2}\end{array}$ & $\begin{array}{l}\text { Removal } \\
\text { of } \mathrm{H}_{2} \mathrm{~S}\end{array}$ \\
\hline $\begin{array}{l}\text { Electricity power generator } \\
\text { (engine or turbine) }\end{array}$ & $1-2$ & $0-1$ & $1-2$ \\
Heating & 1 & 0 & $0-2$ \\
Co-generation & $1-2$ & $0-2$ & $1-2$ \\
$\begin{array}{l}\text { Fuel gas } \\
\text { Introduction in to natural } \\
\text { gas grid }\end{array}$ & 2 & 2 & 2 \\
\hline
\end{tabular}

0, No treatment; 1, partial removal; 2, complete removal

will be distributed between the gas and the liquid phases. In the liquid phase, the total dissolved sulphide is present as $\mathrm{H}_{2} \mathrm{~S}$ and $\mathrm{HS}^{-}$. As the $\mathrm{pK}_{\mathrm{a}}$ of this equilibrium is about 7 , small $\mathrm{pH}$ variations in the $\mathrm{pH}$ range $6-8$ will significantly affect the free $\mathrm{H}_{2} \mathrm{~S}$ concentration;

(b) reduction of the methane yield, and consequently less energy recovery;

(c) necessity of scrubbing of the biogas and posttreatment of effluents to meet discharge standards (Table 1) (Rinzema 1988; Wellinger and Lindeberg 1999), malodour, corrosion of pipings, pumps, etc. (Little et al. 2000; Burgess et al. 2001);

(d) accumulation of inert material in the sludge (e.g. metal sulphides);

(e) growth of filamentous sulphide-oxidising bacteria such as Beggiatoa (Buisman and Lettinga 1990; Rittman and McCarty 2000), a phenomenon that is considered one of the possible causes of bulking sludge (Hossain 2004);

(f) reduced COD-removal due to the presence of sulphide in the effluent;

(g) oxygen demand on the receiving aquatic media thereby killing aquatic life;

(h) high toxicity for humans.

The presence of sulphate in the wastewater during anaerobic treatment can have also positive effects to the treatment:

(a) the sulphide formed can be used to remove heavy metals from the water phase by precipitating them in the form of metal sulphides, thereby preventing the release of heavy metals in the environment (Jacksonmoss and Duncan 1990; Pott and Mattiasson 2004). An additional advantage of heavy metal precipitation is that it lowers the metal toxicity (e.g. arsenic, copper, lead, mercury, tin, chromium, cadmium, cobalt, iron, nickel and zinc) towards anaerobic biomass (Tursman and Cork 1989; Jin et al. 1998); (b) the sulphide formed can provide (in combination with organic sulphur compounds) the sulphur requirements of methanogens that lack assimilatory sulphate reductases (Daniels et al. 1986).

Pollution prevention strategies in general can operate at three different levels: at the source (source control), at the end (end-of-pipe treatment) and at process level. In dealing with the problem of sulphide emission, source control is not a realistic strategy, since the presence of S-containing compounds in wastewater cannot be prevented. End-of-pipe treatment, i.e. the removal of $\mathrm{H}_{2} \mathrm{~S}$ from biogas, is the most established strategy in practice. For that purpose, many different physico-chemical and biological techniques exist, such as biogas scrubbers and adsorption beds. Overviews of these techniques and its applications have been presented in review papers (Smet et al. 1998; Burgess et al. 2001; Noyola et al. 2006). All of these end-of-pipe techniques are implemented as an extra treatment unit. In contrast, process-level control of sulphide emission would imply single-unit wastewater treatment processes. This strategy covers different approaches:

(a) adding selective inhibitors of sulphidogenic bacteria;

(b) raising the $\mathrm{pH}$ in order to obtain predominantly ionic sulphide species;

(c) adding sulphide scavengers;

(d) adding oxygen or nitrate to oxidise sulphide.

It has been repeatedly attempted to selectively inhibit sulphate-reducing bacteria (approach (a)) with compounds such as molybdate (Yadav and Archer 1989; Clancy et al. 1992; Isa and Anderson 2005), divalent transition metals (Clancy et al. 1992), nitrite (O'Reilly and Colleran 2005), and antibiotics (Tanimoto et al. 1989). So far, none of these attempts has been successful, usually due to the compound's inefficacy in continuous systems or to its adverse effects to methanogenesis as well. Approach (b), 
raising the $\mathrm{pH}$ of the anaerobic bioreactor, is based on the acid-base equilibrium between $\mathrm{H}_{2} \mathrm{~S}$ and $\mathrm{HS}^{-}$. The $\mathrm{pK}_{\mathrm{a} 1}$ of this equilibrium is around 7 , which means that the percentage of volatile sulphide $\left(\mathrm{H}_{2} \mathrm{~S}_{\mathrm{aq}}\right)$ will decrease from about $50 \%$ at $\mathrm{pH}=7$ to about $9 \%$ at $\mathrm{pH}=8$. Hence raising the $\mathrm{pH}$ will certainly lead to lower percentages of $\mathrm{H}_{2} \mathrm{~S}$ in the biogas. However, since the bioreactor $\mathrm{pH}$ is restricted to a near neutral range, the result of raising the $\mathrm{pH}$ will often not be sufficient. Moreover, elevating the $\mathrm{pH}$ can be costly or impractical for full-scale operation. Approach (c) makes use of the property of several organic and inorganic compounds to form stable complexes with sulphide, thereby suppressing the release of $\mathrm{H}_{2} \mathrm{~S}$. Examples of used compounds include synthetic scavengers (Hagen and Hartung 1997) and metal ions to precipitate sulphide (Dewaters et al. 1999; Wang and Banks 2006). Due to economical and toxicity reasons, iron is the most used metal for sulphide precipitation, in spite of iron sulphide being more soluble than most other metal sulphides. The long-term application of iron salts to precipitate sulphide has drawbacks, including high chemical costs and high sludge production. The latter may eventually lead to clogging of piping and to reduction of the effective reactor volume. There is as well a series of commercial products available with practical application as sulphide scavengers. These products are directed at control of hydrogen sulphide in the oil industry and wastewater streams. As far as we know, they are not applied in anaerobic wastewater treatment systems; hence the topic appears absent in scientific literature. Approach (d), as an alternative process-level approach, is based simply on the oxidation of sulphide by imposing micro-aerobic or micro-anoxic conditions (Table 2, Fig. 1).

Sulphide oxidation proceeds both biologically and chemically and can take place under aerobic or anaerobic conditions. Chemotrophic microorganisms are involved in the biological aerobic oxidation of sulphide, whereas phototrophic and chemotrophic microorganisms carry out the anaerobic oxidation of sulphide (Brüser et al. 2000; Van Haandel et al. 2006). There is a large phylogenetic diversity among the microorganisms that are able to oxidise sulphide. Most of these microorganisms have also the ability to oxidise other reduced sulphur compounds like elemental sulphur and thiosulphate (Brüser et al. 2000). Under anaerobic conditions, genera of the family of the Chlorobiaceae and Chromatiaceae reduce sulphide while oxidising carbon dioxide. Colourless sulphur bacteria, of which the genus Thiobacillus is a relevant example, oxidise sulphide to elemental sulphur or sulphate using oxygen or nitrate as final electron acceptors (Lens et al. 1998). Both biological and chemical sulphide oxidation is believed to start with the formation of polysulphides $\left(\mathrm{S}_{n}^{2-}\right)$, which can be oxidised and protonated to form elemental sulphur (Steudel 1996). Further oxidation will give rise to the formation of more oxidised sulphur species such as thiosulphate, sulphite and sulphate (Steudel 1996). Under oxygen-limited conditions, sulphur is the major end product of the sulphide oxidation, whereas under fully oxygenated condition, sulphide will be
Table 2 Reaction stoichiometry and Gibbs free energy for sulphide oxidation (values calculated from data provided in Hanselmann 1991)

\begin{tabular}{ll}
\hline Reaction & $\Delta \mathrm{G}^{0^{\prime}}$ kJ/reaction \\
\hline Aerobic & \\
$\mathrm{HS}^{-}+0.5 \mathrm{O}_{2} \rightarrow \mathrm{S}^{0}+\mathrm{OH}^{-}$ & -209.3 \\
$\mathrm{HS}^{-}+2 \mathrm{O}_{2}+\rightarrow \mathrm{SO}_{4}^{2-}+\mathrm{H}^{+}$ & -796.4 \\
Anoxic $($ denitrification) & \\
$\mathrm{HS}^{-}+0.4 \mathrm{NO}_{3}^{-}+1.4 \mathrm{H}^{+} \rightarrow \mathrm{S}^{0}+0.2 \mathrm{~N}_{2}+1.2 \mathrm{H}_{2} \mathrm{O}$ & -196.3 \\
$\mathrm{HS}^{-}+0.67 \mathrm{NO}_{2}^{-}+1.67 \mathrm{H}^{+} \rightarrow \mathrm{S}^{0}+0.33 \mathrm{~N}_{2}+1.33 \mathrm{H}_{2} \mathrm{O}$ & -240.3 \\
$\mathrm{HS}^{-}+1.6 \mathrm{NO}_{3}^{-}+0.6 \mathrm{H}^{+} \rightarrow \mathrm{SO}_{4}^{2-}+0.8 \mathrm{~N}_{2}+0.8 \mathrm{H}_{2} \mathrm{O}$ & -744.3 \\
$\mathrm{HS}^{-}+2.67 \mathrm{NO}_{2}^{-}+1.67 \mathrm{H}^{+} \rightarrow \mathrm{SO}_{4}^{2-}+1.33 \mathrm{~N}_{2}+1.33 \mathrm{H}_{2} \mathrm{O}$ & -920.4 \\
Anoxic $(D N R A)$ & \\
$\mathrm{HS}^{-}+0.25 \mathrm{NO}_{3}^{-}+1.5 \mathrm{H}^{+} \rightarrow \mathrm{S}^{0}+0.25 \mathrm{NH}_{4}^{+}+0.75 \mathrm{H}_{2} \mathrm{O}$ & -122.4 \\
$\mathrm{HS}^{-}+0.33 \mathrm{NO}_{2}^{-}+1.67 \mathrm{H}^{+} \rightarrow \mathrm{S}^{0}+0.33 \mathrm{NH}_{4}^{+}+0.67 \mathrm{H}_{2} \mathrm{O}$ & -119.4 \\
$\mathrm{HS}^{-}+\mathrm{NO}_{3}^{-}+\mathrm{H}^{+}+\mathrm{H}_{2} \mathrm{O} \rightarrow \mathrm{SO}_{4}^{2-}+\mathrm{NH}_{4}^{+}$ & -447.5 \\
$\mathrm{HS}^{-}+1.33 \mathrm{NO}_{2}^{-}+1.67 \mathrm{H}^{+}+1.33 \mathrm{H}_{2} O \rightarrow \mathrm{SO}_{4}^{2-}+1.33 \mathrm{NH}_{4}^{+}$ & -436.7 \\
\hline
\end{tabular}


completely oxidised to sulphate. The relative contribution of chemical sulphide oxidation under oxic conditions has been found to increase under alkaline conditions (González-Sanchéz and Revah 2007).

Several sulphide emission treatment strategies make use of the incomplete oxidation of sulphide to sulphur with recovery of sulphur (Noyola et al. 2006). These strategies are generally focused on the treatment of biogas, off-gas, natural gas or lowstrength wastewaters (Buisman et al. 1990; Janssen et al. 1995, 1998; Annachhatre and Suktrakoolvait 2001). The principle of these systems is based on the conversion of sulphide (after absorption into the liquid phase in case of gas treatment) to elemental sulphur using sulphide oxidising microorganisms (usually Thiobacillus) and a controlled oxygen supply. An important prerequisite of these processes is that the sulphur particles formed must have good settling properties so that they can be recovered by sedimentation. For this purpose, long solid retention times should be applied, to enable the formation of aggregates of biologically produced sulphur particles and immobilised microorganisms (Janssen et al. 1995). The techniques described in literature that make use of nitrate to oxidise sulphide are not primarily directed at sulphur recovery but aim at sulphide oxidation or nitrate removal (Sect. 2.2).

The aim of this short review is to give an overview of strategies for process-level control of sulphide emission, with focus on the introduction of microaerobic and micro-anoxic conditions during anaerobic wastewater treatment. The results of research studies dealing with sulphide oxidation by adding limited amounts of oxygen or nitrate (or nitrite) for will be summarised, and feasibility of the applied treatment strategies will be discussed.

\section{Wastewater treatment processes for simultaneous organic carbon removal and micro-aerobic/micro-anoxic sulphide oxidation}

\subsection{Treatment of S-containing wastewaters under micro-aerobic conditions}

The simplest method of desulphurisation is the introduction of micro-aerobic conditions in order to oxidise sulphide. Such conditions can be generated in anaerobic bioreactors by dosing controlled amounts of oxygen or air as an oxidant or electron acceptor in the chemical or biological oxidation of sulphide. Despite the toxicity exerted by oxygen against obligate anaerobes like methanogens, its moderate introduction to anaerobic bioreactors is not expected to have a harmful impact to the biomass, mainly due to the limited penetration depth of oxygen in biofilms (Kato et al. 1993). The introduction of limited amounts of air is a general practice in agricultural anaerobic digesters: it is estimated that worldwide over 3,000 units are operated under such conditions (A. Wellinger, pers. comm.). Manure is one of the feedstocks treated in these digesters. An air flow of $2-6 \%(\mathrm{v} / \mathrm{v})$ of the biogas flow is introduced, mostly into the digester's headspace or alternatively to a separate reactor after the digester. Occasionally, the air is added to the liquid influent. The sulphide is oxidised to elementary sulphur, which is disposed off together with the digestate (O. Jönsson and $\mathrm{T}$. Al Seadi, pers. comm.). In spite of this, the scientific literature about micro-aerobic reactor operation for sulphide removal is rather limited. Table 3 gives an overview of the systems used for studying microaerobic sulphide oxidation. All of them are lab-scale systems. The studies cover a wide range of loading conditions in terms of sulphate, oxygen and organic COD; and many different reactor configurations have been applied. Moreover, the purpose of sulphide oxidation varied from diminishing biogas sulphide levels in bioreactors operated at low S-load (van der Zee et al. 2007) to suppressing sulphide toxicity in bioreactors operated at high S-loads (Zitomer and Shrout 2000; Khanal and Wang 2003a, b, 2006; Zhou et al. 2007). Sections 2.1.1-2.1.3 discuss the different aspects of micro-aerobic bioreactor operation for sulphide oxidation.

\subsubsection{Reactor configuration}

All bioreactors used for studying micro-aerobic sulphide oxidation were up-flow columns with a carrier material, except the chemostat used by (Khanal and Huang 2003b). Oxygen or air was introduced either directly into the reactor (Zitomer and Shrout 2000; van der Zee et al. 2007; Zhou et al. 2007) or into the combined flow of effluent and biogas, right before this mixture entered a reservoir acting as a gas/liquid separator (Khanal and Wang 


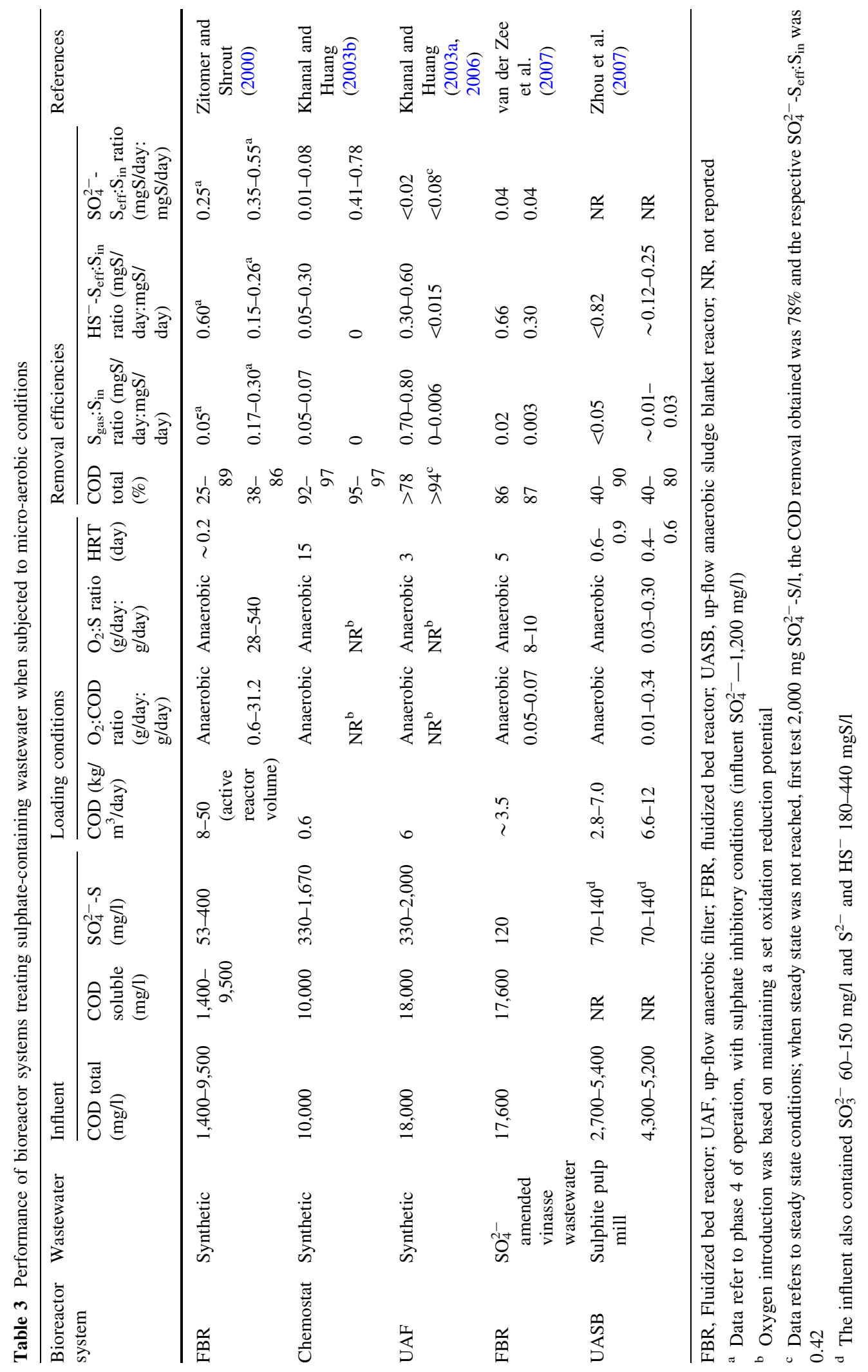


2003a, b) or as a three-phase separator for biogas, effluent and elemental sulphur (Khanal and Huang 2006). In the latter systems, the oxygen-containing biogas from the separation reservoir returns to the bioreactor, and the sulphide-free effluent is discharged. Although these systems can no longer be considered single-unit micro-aerobic bioreactors, and although sulphide oxidation will mainly take place in the separation reservoir, it was decided to include them in Table 3 since the conditions in the bioreactor are clearly micro-aerobic and since the combined reactor-separator system has a single integrated gas cycle. In contrast, reactor systems consisting of an anaerobic bioreactor in series with an aerobic bioreactor for oxidizing the sulphide in the recycled effluent (Fox and Venkatasubbiah 1996; Chuang et al. 2005) have not been included, since the gas phases of the aerobic and the anaerobic unit are separated, and the oxygen that enters the anaerobic bioreactor is limited to that dissolved in the recycled effluent.

The oxygen dosing regime differed considerably between the reactor studies. Zhou et al. (2007) based air dosage essentially on avoiding serious sludge washout from the bioreactor, taking into account the theoretically amount of oxygen required to oxidise sulphide to sulphur. Van der Zee et al. (2007) based the amount of air to be injected on the S-load to the system, using a super-stoichiometric ratio of 8$10 \mathrm{~mol}_{2}$ per mol S. Zitomer and Shrout (2000) did not use any specific criterion for dosing the amount of air introduced. These authors investigated the effect of increasing air load $(0-675 \mathrm{ml}$ air $/ \mathrm{min})$ on improving oxygen transfer conditions. Khanal and Huang (2003a, b, 2006) used an oxidation reduction potential (ORP) controlled oxygen injection system with a pre-set target ORP based on that ORP correlates with dissolved oxygen concentration (Peddie et al. 1990). The selection of initial ORP target values was arbitrary with a belief that the injected oxygen would be enough to eliminate sulphide completely. The utilization of an ORP based method for oxygen dosage is an attractive option because under typical anaerobic operating conditions the concentration of dissolved oxygen is practically zero. However, the choice of correlating measured ORP with dissolved oxygen concentration may not be useful. Janssen et al. (1995, 1998), while investigating the use of ORP to control the injection of oxygen for the treatment of gas streams in a gas-lift bioreactor, found that the ORP was determined by the sulphide concentration and that the dissolved oxygen concentration is less important, which is in contrast to the findings of Khanal and Huang (2003a, b, 2006).

\subsubsection{Sulphide oxidation and product formation in micro-aerobic bioreactors}

Anaerobic treatment at S-limiting conditions usually leads to complete reduction of all the inorganic and organic S-containing compounds present in the wastewater. The ratio (effluent + biogas)-sulphideS:influent-S $\left(\left(\mathrm{HS}^{-}-\mathrm{S}_{\text {eff }}+\mathrm{S}_{\mathrm{gas}}\right): \mathrm{S}_{\text {in }}\right)$ will be close to 1. The data in Table 3 show that the ratio $\left(\mathrm{HS}^{-}\right.$$\left.S_{\text {eff }}+S_{\text {gas }}\right): S_{\text {in }}$ of the micro-aerobically operated bioreactors was always lower than 1 , indicating that introduction of micro-aerobic conditions promoted sulphide oxidation. In all bioreactor studies except in the system used by Zitomer and Shrout (2000), the levels of sulphide in the biogas decreased considerably (at least 1.6 times), with biogas sulphide levels corresponding to a maximum of about $3 \%$ of the influent-S (Table 3). The distribution of sulphide over biogas and effluent will depend on the operation conditions, mainly on the $\mathrm{pH}$, the volume of biogas produced and the oxygenation dosing regime. It is most likely that the increase in the biogas sulphide level reported by Zitomer and Shrout (2000), was due to liquid phase stripping of $\mathrm{H}_{2} \mathrm{~S}$, as a result of the high oxygenation loads (540 $\mathrm{g} \mathrm{O}_{2} / \mathrm{g} \mathrm{S}_{\text {in }}$ per day).

Elemental sulphur and sulphate have been suggested as the main products of micro-aerobic sulphide oxidation in the systems listed in Table 3 . The general tendency of introduction of micro-aerobic conditions in the reactor systems was an increase in the ratio effluent sulphate-S:influent-S $\left(\mathrm{SO}_{4}^{2-}-\mathrm{S}_{\text {eff:- }}\right.$ $\mathrm{S}_{\mathrm{in}}$ ), an observation that was more evident at higher oxygen loads $\left(\mathrm{O}_{2}: \mathrm{S}_{\text {in }}\right)$ (Table 3$)$. A substantial increase in the sulphate concentration has been reported by Zitomer and Shrout (2000) and Khanal and Huang (2003b). Interestingly, in the bioreactor system study by Van der Zee et al. (2007), introduction of excess air $\left(\mathrm{O}_{2}: \mathrm{S}\right.$ load, 8-10) did not raise the effluent sulphate concentration, which indicated that the net sulphide oxidation was incomplete, i.e. to elemental sulphur and/or polysulphide. The S- 
balances of the remaining reactor studies also suggest that elemental sulphur and/or polysulphide are the main reaction products. When measured, thiosulphate was generally only detected during the first days of aeration/oxygenation (Khanal and Huang 2003a, 2006).

\subsubsection{COD removal in micro-aerobic bioreactors}

The efficiency of organic matter removal improved in most treatment systems with introduction of microaerobic conditions (Table 3). The $\mathrm{O}_{2}$ : COD ratios applied to the reactor systems varied broadly between the different studies (0.01-31). At low $\mathrm{O}_{2}$ : $\mathrm{COD}$ ratios, oxygen will not contribute to a large extent to the overall COD removal. However, if the oxygen load is very high, as in the studies of Zitomer and Shrout (2000) and Khanal and Huang (2003b) (Table 3), this contribution will be significant. Facultative heterotrophs were found to consume as high as 28 and $66 \%$ of the influent COD in the investigations of Zitomer and Shrout (2000) and Khanal and Huang (2003b), respectively. In addition, oxygen may affect COD-removal indirectly, by alleviating sulphide toxicity towards methanogens in wastewaters containing elevated concentrations of sulphate (Zitomer and Shrout 2000; Khanal and Huang 2003a, b, 2006; Zhou et al. 2007).

\subsection{Using nitrate or nitrite to control sulphide generation during treatment of S-containing wastewaters}

As alternatives for oxygen, nitrate and nitrite can be used to control sulphide generation during treatment of S-containing wastewaters. Nitrate and nitrite are usual constituents of many wastewaters, or can be generated separately, in a nitrification reactor. Compared to oxygen, nitrate and nitrite have the advantage of being highly soluble. This means that their use does not require applying an external gas flow and, consequently, that there will be less stripping of gaseous sulphide. Reduction of nitrate and nitrite follows either one of two possible mechanisms, denitrification or ammonification, yielding nitrogen gas or ammonia, respectively. The latter process, dissimilatory nitrate reduction to ammonia (DNRA), is thermodynamically less favourable than denitrification but requires less nitrate or nitrite than denitrification to oxidise one mole of sulphide (Table 2). DNRA is associated with fermentative and obligate anaerobic bacteria (Kaspar et al. 1981), and has also been reported for two pure cultures of SRB (Dannenberg et al. 1992). DNRA may be the preferred pathway at high carbon to nitrogen ratios (Akunna et al. 1992). The nature of the carbon source has also been suggested to influence the reduction pathways of nitrogen oxides (Percheron et al. 1998).

The feasibility of using nitrate and nitrite as electron acceptors for sulphide oxidation has been demonstrated in several reactor studies (Gommers et al. 1988; Krishnakumar and Manilal 1999; Kleerebezem and Mendez 2002; Reyes-Avila et al. 2004; Sierra-Alvarez et al. 2005; Vaiopoulou et al. 2005; Cardoso et al. 2006; Gadekar et al. 2006; Lau et al. 2006; Mahmood et al. 2007). A common feature of these studies was that the reaction was studied under fully anoxic conditions and with sulphide as a main, usually the sole, electron donor. In many of these studies, the concentration of nitrate relative to that of sulphide determined whether sulphide was oxidised to elemental sulphur or sulphate. The mechanism of nitrate/nitrite reduction was denitrification. When both sulphide and organic compounds were present as electron donors, simultaneous autotrophic and heterotrophic (i.e. mixotrophic) denitrification could be observed (Gommers et al. 1988; Lens et al. 2000; Reyes-Avila et al. 2004; Sierra-Alvarez et al. 2005). A specific application of sulphide oxidation by autotrophic denitrification is the Denitrifying Ammonium Oxidation (DEAMOX) process, a process that combines Anaerobic Ammonium Oxidation (ANAMMOX) with the reduction of nitrate to nitrite by sulphide (Kalyuzhnyi et al. 2006a, b, 2007). In this process, the DEAMOX reactor receives a mixture of two wastewater streams, the ammonium and sulphide-rich effluent from an anaerobic reactor and the nitrate (and sulphate-) rich effluent from a nitrification reactor treating part of the anaerobic effluent. Although the sulphide load to the DEAMOX reactor was $\sim 75 \%$ higher than the stoichiometric amount required for the reduction of nitrate to nitrite $\left(\mathrm{HS}^{-}+4 \mathrm{NO}_{3}^{-} \rightarrow \mathrm{SO}_{4}^{2-}+4 \mathrm{NO}_{2}+\mathrm{H}^{+} ; \Delta \mathrm{G}^{0^{\prime}}=-480\right.$ $\mathrm{kJ} /$ reaction, complete removal of sulphide, along with $\sim 80 \%$ sulphate recovery, was achieved, indicating that ANAMMOX $\quad\left(\mathrm{NH}_{4}^{+}+\mathrm{NO}_{2}^{-} \rightarrow \mathrm{N}_{2}+2 \mathrm{H}_{2} \mathrm{O}\right.$; $\Delta \mathrm{G}^{0^{\prime}}=-358 \mathrm{~kJ} /$ reaction) did not completely 
outcompete autotrophic denitrification $\left(0.375 \mathrm{HS}^{-}+\right.$ $\mathrm{NO}_{2}^{-}+0.625 \mathrm{H}^{+} \rightarrow 0.375 \mathrm{SO}_{4}^{2-}+0.5 \mathrm{~N}_{2}+0.5 \mathrm{H}_{2} \mathrm{O}$; $\Delta \mathrm{G}^{0^{\prime}}=-345 \mathrm{~kJ} /$ reaction) for nitrite consumption (Kalyuzhnyi et al. 2007).

The feasibility of combined methanogenic/anoxic treatment of nitrate and/or nitrite-containing wastewaters on single-unit bioreactors has been reported in several research papers (Hendriksen and Ahring 1996; Im et al. 2001; Núñez and Martínez 2001; Zhang and Verstraete 2001; Tai et al. 2006). These studies showed that nitrate and nitrite could be efficiently removed by denitrification, while methanogenesis accounted for the major part of COD-removal. Evidently, the property of nitrate and nitrite, and especially of the more reduced denitrification intermediates nitric and nitrous oxide, to inhibit methanogenesis (Tugtas and Pavlostathis 2007) does not obstruct combining both microbial processes in one reactor. For example, even though severe inhibition of nitrite to acetoclastic methanogenesis by anaerobic sludge has been reported, with $\mathrm{IC}_{50^{-}}$ concentrations as low as 4.0-6.4 $\mathrm{mg} \mathrm{NO}_{2}^{-}-\mathrm{N} / 1$ (O'Reilly and Colleran 2005), it has been shown that complete removal of nitrite and 92-97\% removal of COD could be achieved in an expanded granular sludge bed (EGSB) reactor at loads up to $0.9 \mathrm{~g} \mathrm{NO}_{2}^{-}$$\mathrm{N} / \mathrm{l} /$ day and $6.5 \mathrm{~g} \mathrm{COD} / \mathrm{l} /$ day (Zhang and Verstraete 2001). Inhibition of methanogenesis, along with the thermodynamic advantage of nitrate and nitrite reduction over methanogenesis, make it likely that combined methanogenic/anoxic environments will show nitrate reduction to proceed prior to, rather than simultaneous with, methanogenesis. Such a phased behaviour has indeed been reported in several batch studies, although usually only to a certain extent, and mainly due to inhibition rather than to competition (Balderston and Payne 1976; Chen and Lin 1993; Roy and Conrad 1999). Clear evidence for distinct denitrifying and methanogenic zones in nitrate-amended anaerobic bioreactors has not been reported. Nevertheless, the upward trend observed in the sludge blanket for changes in the size, strength and colour of the granules in a nitrate-amended up-flow anaerobic sludge blanket (UASB) reactor studied by Hendriksen and Ahring (1996) suggested that denitrification was mainly associated to the bottom part of the reactor.

Although both anoxic sulphide oxidation and combined methanogenic/anoxic wastewater treatment have been widely studied, publications about adding nitrate or nitrite to otherwise anaerobic reactors, to oxidise the sulphide resulting from anaerobic treatment of S-containing organic wastewaters are scarce. In the anaerobic-anoxic-oxic process (ANANOX), the nitrate-containing flow from the nitrifying oxic stage is recycled to the anoxic zone, which is either the second part of an anaerobic-aerobic baffled reactor (Garuti et al. 2001) or the anoxic part of a hybrid ANANOX-reactor (Tilche et al. 1994). In this zone, nitrate may act as electron acceptor for the oxidation of residual organic COD and sulphide. Garuti et al. (2001) evaluated the fate of sulphate and sulphide in the anoxic compartment of the baffled reactor that was part of a full-scale ANANOXreactor. The results were equivocal: the sulphate concentration was seen to increase but so did the sulphide concentration. The reason for this phenomenon is not clear but in this specific case it appeared that the presence of a large excess of nitrate was not a guarantee for efficient sulphide oxidation.

\section{Discussion}

Oxidation of sulphide in anaerobic bioreactors by introducing limited amounts of oxygen or nitrate (or nitrite) may provide a relatively simple strategy for reducing the levels of sulphide in the reactors' biogas and effluent. The prerequisites for the feasibility of these processes are (i) that sulphide oxidation successfully competes with other oxidative processes like aerobic or anoxic heterotrophic oxidation of organic COD and (ii) that sulphide oxidation is faster than re-reduction of the oxidised sulphur species. The far-reaching decrease of the sulphide emission reported in the micro-aerobic reactor studies discussed in this paper indicate that these conditions can be met. The results obtained with nitrate and nitrite are less unequivocal. Although the feasibility of both anoxic sulphide oxidation and combined methanogenic/anoxic wastewater treatment have been demonstrated, the use of 'micro-anoxic' conditions, i.e. adding limited amounts of nitrate or nitrite to oxidise the sulphide in anaerobic bioreactors treating S-containing organic wastewaters has hardly been evaluated. The lack of publications on 'micro-anoxic' sulphide oxidation may be a sign of inefficiency, i.e. it indicates that the prerequisites mentioned above may not be met. 
When micro-aerobic conditions were imposed to otherwise anaerobic bioreactors, elevated effluent sulphate concentrations were usually observed but the sulphur balances showed that the fraction of influent$\mathrm{S}$ recovered as sulphate-S was always lower and often much lower than $100 \%$. Only a small or even negligible part of this gap could be attributed to sulphide-S in biogas and effluent. Therefore, it is most likely that elemental sulphur and/or polysulphides were the main reaction products of sulphide oxidation in the reactor studies discussed, an assumption that was furthermore supported by the oftenreported visual evidence of elemental sulphur formation. Sulphide oxidation by limited amounts of nitrate and nitrite is also expected to yield elemental sulphur rather than sulphate. The formation of elemental sulphur poses a possible disadvantage of methods to oxidise sulphide inside an anaerobic bioreactor. This includes the risk of clogging, reduction of the space available for biomass, as well as the risk of excessive sulphide formation in case of unstable operation conditions. A way to avoid problems due to sulphur accumulation is to control its formation in an isolated part of the reactor system. The system proposed by Khanal and Huang (2006), oxygenation of the recycle flow in combination with elemental sulphur separation, may serve this purpose. This alternative is relatively simple to integrate in the treatment system.

Addition of oxygen or nitrate (or nitrite) will inevitably change the microbial composition of the sludge, which in turn is likely to affect the sludge's physical characteristics. The growth of aerobic and denitrifying heterotrophs is generally associated with fluffy biomass, whereas several autotrophic sulphide oxidisers are filamentous organisms. Hendriksen and Ahring (1996) saw that the structure of the granules deteriorated, and experienced sludge washout problems, when operating an UASB-reactor under combined methanogenic-denitrifying conditions. Zhou et al. (2007) noticed that the proportion of rodshaped methanogens almost disappeared while cocci and filaments became the predominant bacterial morphologies in their oxygenated UASB. Hence, it should be taken into account that sludge washout may occur. Using a support material, as has been done in most of the studies listed in Table 3, may help to avoid sludge washout. Alternatively, the sludge's stability can be increased by imposing changes like applying higher upflow velocities (Hendriksen and Ahring 1996).
Adding oxygen, air or nitrate/nitrite to anaerobic bioreactors will dilute the biogas with $\mathrm{N}_{2}$ (from air or denitrification), $\mathrm{O}_{2}$ (the fraction that fails to diffuse in the liquid phase and does not react biologically or chemically) and surplus $\mathrm{CO}_{2}$ (from heterotrophic activity). $\mathrm{N}_{2}$ may be oxidised to the greenhouse gas $\mathrm{NO}_{x}$ when the biogas is combusted. $\mathrm{O}_{2}$ in biogas can lead to an explosive mixture, albeit only at excessively high levels; biogas in air is explosive in the range of $6-12 \%$, depending on the methane content (Wellinger and Lindeberg 1999). The dilution of biogas may also give rise to combustibility problems. $\mathrm{N}_{2}$ can be removed from gas streams by membranes or by low temperature pressure swing adsorption (PSA). However, removal is expensive (Wellinger and Lindeberg 1999).

At present, sulphide emission control during anaerobic wastewater treatment mainly focused on end-of-pipe solutions and on process-level control by addition of sulphide scavengers. A considerable number of patents are available on these subjects. These patents refer to biogas treatment or bioreactor effluent treatment (involving stripping of dissolved sulphide in some cases) and aim mainly at sulphur production in a separate reactor when oxygen or air is used. The practice of introducing air to anaerobic bioreactor systems appears to be increasing, in particular in farm-scale anaerobic digesters. Nitrate is used in practice to control sulphide formation in sewer systems (Bentzen et al. 1995; Mathioudakis et al. 2006) but, as far as we know, not in anaerobic bioreactor systems.

From the information presented in this paper it is clear that there are still many uncertainties about the feasibility of using limited amounts of oxygen or nitrate to control sulphide emission by anaerobic bioreactors. Future research should focus on optimising the use of oxygen and exploring the use of nitrate for micro-aerobic and 'micro-anoxic' sulphide oxidation, respectively, e.g. by determining where, how and how much should be dosed, determining the contribution of chemical sulphide oxidation, and by evaluating the long-term effects of micro-aerobic or 'microanoxic' reactor operation on the process stability. It is also clear that the scope of applications investigated up to present is limited and must be broadened. The information provided in the studies reviewed could be used as a starting point to expand the application of this technique to other anaerobic bioreactor treatment 
systems (e.g. anaerobic treatment in suspended growth bioreactors, anaerobic treatment of excess activated sludge, of the organic fraction of municipal solid waste and animal manure).

Apart from the field of application of introduction of limited amounts of oxygen or nitrate (or nitrite) to biologically (or chemically) oxidise sulphide reviewed in this paper, there are other potential fields of application of this technique such as micro-aerobic domestic wastewater treatment (Basu and Mino 1993; Basu et al. 1995), sewer emission control (this topic was briefly referred to in the paper) (e.g. Ochi et al. 1998), contaminated sediment remediation, natural occurring processes (marine sediment chemical-biological interactions), which definitely show the significance of this application.

Acknowledgements The authors thank the Spanish Ministry of Education and Science (project CTM 2005-02967/TECNO) for financial support and P. Wheeler, AEA Technology Environment, A. Wellinger, Nova Energie, O. Jönsson, The Swedish Gas Centre and T. Al Seadi, University of Southern Denmark, for their help with the implementation in practice of micro-aerobic conditions in anaerobic bioreactors.

\section{References}

Akunna JC, Bizeau C, Moletta R (1992) Denitrification in anaerobic digesters: possibilities and influence of waste water COD/N-NOx ratio. Environ Technol 13(9):825-836

Annachhatre AP, Suktrakoolvait S (2001) Biological sulphide oxidation in a fluidized bed reactor. Environ Technol 22(6):661-672

Balderston WL, Payne WJ (1976) Inhibition of methanogenesis in salt marsh sediments and whole-cell suspensions of methanogenic bacteria by nitrogen oxides. Appl Environ Microbiol 32(2):264-269

Basu SK, Mino T (1993) Domestic waste-water treatment using microaerophilic upflow sludge bed reactor. Environ Technol 14(5):413-422

Basu SK, Mino T, Oleszkiewicz JA (1995) Novel application of sulphur metabolism in domestic wastewater treatment. Can J Civ Eng 22:1217-1223

Bentzen G, Smith AT, Bennett D, Webster NJ, Reinholt F, Sletholt E, Hobson J (1995) Controlled dosing of nitrate for prevention of $\mathrm{H}_{2} \mathrm{~S}$ in a sewer network and the effects on the subsequent treatment processes. Water Sci Technol 31(7):293-302

Brüser T, Lens PNL, Trüper HG (2000) The biological sulphur cycle. In: Lens PNL, Hulshoff Pol LW (eds) Environmental technologies to treat sulfur pollution - principles and engineering. IWA Publishing, London, pp 47-85

Buisman CJN, Lettinga G (1990) Sulphide removal from anaerobic waste treatment of a paper mill. Water Res 24(3):313-319
Buisman CJN, Geraats BG, Ijspeert P, Lettinga G (1990) Optimization of sulphur production in a biotechnological sulphide-removing reactor. Biotechnol Bioeng 35: 50-56

Burgess JE, Parsons SA, Stuetz RM (2001) Developments in odour control and waste gas treatment biotechnology: a review. Biotechnol Adv 19:35-63

Cardoso RB, Sierra-Alvarez R, Rowlette P, Razo-Flores E, Gómez J, Field JA (2006) Sulfide oxidation under chemolithoautotrophic denitrifying conditions. Biotechnol Bioeng 95(6): 1148-1157

Chen KC, Lin YF (1993) The relationship between denitrifying bacteria and methanogenic bacteria in a mixed culture system of acclimated sludges. Water Res 27(12): 1749-1759

Chuang SH, Pai TY, Horng RY (2005) Biotreatment of sulfaterich wastewater in an anaerobic/micro-aerobic bioreactor system. Environ Technol 26(9):993-1001

Clancy PB, Venkataraman N, Lynd LR (1992) Biochemical inhibition of sulfate reduction in batch and continuous anaerobic digesters. Water Sci Technol 25(7):51-60

Daniels L, Belay N, Rajagopal BS (1986) Assimilatory reduction of sulfate and sulfite by methanogenic bacteria. Appl Environ Microbiol 51:703-709

Dannenberg S, Kroder M, Dilling W, Cypionka H (1992) Oxidation of $\mathrm{H}_{2}$, organic compounds and inorganic sulfur compounds coupled to reduction of $\mathrm{O}_{2}$ or nitrate by sulfate-reducing bacteria. Arch Microbiol 158:93-99

Dewaters JE, Zander AK, Grimberg SJ (1999) The use of ferric salts for controlling sulfide odors in high-strength pulp and paper manufacturing wastes. Environ Eng Sci 16(6):441-450

Fox P, Venkatasubbiah V (1996) Couple anaerobic/aerobic treatment of high-sulfate wastewater with sulfate reduction and biological sulfide oxidation. Water Sci Technol 34(5-6):359-366

Gadekar S, Nemati M, Hill GA (2006) Batch and continuous biooxidation of sulphide by Thimicrospira sp. CVO: reaction kinetics and stoichiometry. Water Res 40(12): 2436-2446

Garuti A, Giordano A, Pirozzi F (2001) Full-scale ANANOX ${ }^{\circledR}$ system performance. Water SA 27(2):189-198

Gommers PJF, Bijleveld W, Kuenen JG (1988) Simultaneous sulphide and acetate oxidation in a denitrifying fluidized bed reactor-I start-up and reactor performance. Water Res 22(9):1075-1083

González-Sanchéz A, Revah S (2007) The effect of chemical oxidation on the biological sulfide oxidation by an alkaliphilic sulfoxidizing bacterial consortium. Enzyme Microb Technol 40:292-298

Hagen CE, Hartung RW (1997) New chemical treatment method controls wastewater system odor. Pulp Pap 71(11):81-89

Hanselmann KW (1991) Microbial energetics applied to waste repositories. Experientia 47:645-687

Hendriksen HV, Ahring BK (1996) Integrated removal of nitrate and carbon in an upflow anaerobic sludge blanket (UASB) reactor: operating performance. Water Res 30(6): 1451-1458

Hossain F (2004) Activated sludge bulking: a review of causes and control strategies. J Instn Engrs (India) 85:1-6 
Hulshoff Pol LW, Lens PNL, Stams AJM, Lettinga G (1998) Anaerobic treatment of sulphate-rich wastewaters. Biodegradation 9:213-224

Im J-H, Woo H-J, Choi M-W, Han K-B, Kim C-W (2001) Simultaneous organic and nitrogen removal from municipal landfill leachate using an anaerobic-aerobic system. Water Res 35(10):2403-2410

Isa MH, Anderson GK (2005) Molybdate inhibition of sulphate reduction in two-phase anaerobic digestion. Process Biochem 40(6):2079-2089

Jacksonmoss CA, Duncan JR (1990) Anaerobic-digestion at high sulphate concentrations. J Am Leather Chem As 85(10):376-382

Janssen AJH, Sleyster R, van der Kaa C, Jochemsen A, Bontsema J, Lettinga G (1995) Biological sulphide oxidation in a fed-batch reactor. Biotechnol Bioeng 47: 327-333

Janssen AJH, Meijer S, Bontsema J, Lettinga G (1998) Application of the redox potential for controlling a sulfide oxidizing bioreactor. Biotechnol Bioeng 60(2):147-155

Jin P, Bhattacharya SK, Williams CJ, Zhang C (1998) Effects of sulphide addition on copper inhibition in methanogenic systems. Water Res 32(4):977-988

Kalyuzhnyi S, Gladchenko M, Mulder A, Versprille B (2006a) DEAMOX - new biological nitrogen removal process based on anaerobic ammonia oxidation coupled to sulphide-driven conversion of nitrate into nitrite. Water Res 40(19):3637-3645

Kalyuzhnyi S, Gladchenko M, Mulder A, Versprille B (2006b) DEAMOX - new anaerobic process of nitrogen removal. Water Sci Technol 54(8):163-170

Kalyuzhnyi S, Gladchenko M, Mulder A, Versprille B (2007) Comparison of quasisteady-state performance of the DEAMOX process under intermittent and continuous feeding and different nitrogen loading rates. Biotechnol J 2:894-900

Kaspar HF, Tiedje JM, Firestone RB (1981) Denitrification and dissimilatory nitrate reduction to ammonium in digested sludge. Can J Microbiol 27(9):878-885

Kato MT, Field JA, Lettinga G (1993) High tolerance of methanogens in granular sludge to oxygen. Biotechnol Bioeng 42(11):1360-1366

Khanal SK, Huang JC (2003a) Anaerobic treatment of high sulfate wastewater with oxygenation to control sulfide toxicity. J Environ Eng 129(12):1104-1111

Khanal SK, Huang JC (2003b) ORP-based oxigenation for sulfide control in anaerobic treatment of high sulfate wastewater. Water Res 37:2053-2062

Khanal SK, Huang JC (2006) Online oxygen control for sulfide oxidation in anaerobic treatment of high-sulfate wastewater. Water Environ Res 78(4):397-308

Kleerebezem R, Mendez R (2002) Autotrophic denitrification for combined hydrogen sulfide removal from biogas and post-denitrification. Water Sci Technol 45(10):349-356

Koster IW, Rinzema A, de Vegt AL, Lettinga G (1986) Sulfide inhibition of the methanogenic activity of granular sludge at different $\mathrm{pH}$ levels. Water Res 21(12):1561-1567

Krishnakumar B, Manilal VB (1999) Bacterial oxidation of sulphide under denitrifying conditions. Biotechnol Lett 21(5):437-440
Lau GN, Sharma KR, Chen GH, van Loosdrecht MCM (2006) Integration of sulphate reduction, autotrophic denitrification and nitrification to achieve low-cost excess sludge minimisation for Hong Kong sewage. Water Sci Technol 53(3):227-325

Lens PNL, Visser ANL, Janssen AJH, Hulshoff Pol LW, Lettinga G (1998) Biotechnological treatment of sulfaterich wastewaters. Crit Rev Environ Sci Technol 28(1): 41-88

Lens PNL, Sipma J, Hulshoff Pol LW, Lettinga G (2000) Effect of nitrate on acetate degradation in a sulfidogenic staged reactor. Water Res 34(1):31-42

Little BJ, Ray RI, Pope RK (2000) Corrosion and sulfur bacteria. In: Lens PNL, Hulshoff Pol LW (eds) Environmental technologies to treat sulfur pollution principles and engineering, 1st edn. IWA Publishing, London, pp 491-513

Mahmood Q, Zheng P, Cai J, Wu D, Hu B, Li J (2007) Anoxic sulphide biooxidation using nitrite as electron acceptor. $\mathrm{J}$ Hazard Mater (in press), corrected proof

Mathioudakis VL, Vaiopoulou E, Aivasidis A (2006) Addition of nitrate for odor control in sewer networks: laboratory and field experiments. Global NEST J 8(1):37-42

Noyola A, Morgan-Sagastume JM, López-Hernández JE (2006) Treatment of biogas produced in anaerobic reactors for domestic wastewater: odor control and energy/ resource recovery. Rev Environ Sci Biotechnol 5(1): 93-114

Núñez LA, Martínez B (2001) Evaluation of an anaerobic/ aerobic system for carbon and nitrogen removal in slaughterhouse wastewater. Water Sci Technol 44(4): 271-277

Ochi T, Kitagawa M, Tanaka S (1998) Controlling sulphide generation in force mains by air injection. Water Sci Technol 37(1):87-95

O'Reilly C, Colleran E (2005) Toxicity of nitrite toward mesophilic and thermophilic sulphate-reducing, methanogenic and syntrophic populations in anaerobic sludge. $\mathrm{J}$ Ind Microbiol Biotechnol 32(2):46-52

Oude Elferink SJWH, Visser A, Hulshoff Pol LW, Stams AJM (1994) Sulfate reduction in methanogenic bioreactors. FEMS Microbiol Rev 15:119-136

Peddie CC, Maviniv DS, Jenkins DJ (1990) Use of ORP for monitoring and control of aerobic sludge digestion. J Environ Eng 116(3):461-471

Percheron G, Michaud S, Bernet N, Moletta R (1998) Nitrate and nitrite reduction of a sulphide-rich environment. $\mathrm{J}$ Chem Technol Biotechnol 72:213-220

Pott BM, Mattiasson B (2004) Separation of heavy metals from water solutions at the laboratory scale. Biotechnol Lett 26(5):451-456

Reyes-Avila J, Razo-Flores E, Gomez J (2004) Simultaneous biological removal of nitrogen, carbon and sulfur by denitrification. Water Res 38(14-15):3313-3321

Rinzema A (1988) Anaerobic treatment of wastewater with high concentrations of lipid or sulphate. $\mathrm{PhD}$ thesis, Wageningen Agricultural University, the Netherlands

Rittmann BE, McCarty PL (eds) (2000) Environmental biotechnology principles and application. McGraw-Hill Companies Inc., New York, pp 340-347 
Roy R, Conrad R (1999) Effect of methanogenic precursors (acetate, hydrogen, propionate) on the suppression of methane production by nitrate in anoxic rice field soil. FEMS Microbiol Ecol 28(1):49-61

Sierra-Alvarez R, Guerrero F, Rowlette P, Freeman S, Field JA (2005) Comparison of chemo-, hetero- and mixotrophic denitrification in laboratory-scale UASBs. Water Sci Technol 52(1-2):337-342

Shin HS, Jung JY, Bae BU, Paik BC (1995) Phase-separated anaerobic toxicity assays for sulfate and sulfide. Water Environ Res 67:802-806

Smet E, Lens P, Van Langenhove H (1998) Treatment of waste gases contaminated with odorous sulfur compounds. Crit Rev Environ Sci Technol 28(1):89-117

Steudel R (1996) Mechanism for the formation of elemental sulfur from aqueous sulfide in chemical and microbiological desulfurization processes. Ind Eng Chem Res 35:1417-1423

Tai CS, Singh KS, Grant SR (2006) Combined removal of carbon and nitrogen in an integrated UASB-jet loop reactor bioreactor system. J Environ Eng 132(6):624-637

Tanimoto Y, Tasaki M, Okamura K, Yamaguchi M, Minami K (1989) Screening growth inhibitors of sulfate-reducing bacteria and their effects on methane fermentation. J Ferment Bioeng 68(5):353-359

Tilche A, Bortone G, Forner G, Indulti M, Stante L, Tesini O (1994) Combination of anaerobic digestion and denitrification in a hybrid upflow anaerobic filter integrated in a nutrient removal treatment plant. Water Sci Technol 30(12):405-414

Tugtas AE, Pavlostathis SG (2007) Inhibitory effects of nitrogen oxides on a mixed methanogenic culture. Biotechnol Bioeng 96(3):444-455

Tursman JF, Cork DJ (1989) Influence of sulphate and sulfitereducing bacteria on anaerobic digestion technology. In: Biological waste treatment. Alan R Liss Inc., New York, pp 273-281
Vaiopoulou E, Melidis P, Aivasidis A (2005) Sulphide removal in wastewater from petrochemical industries by autotrophic denitrification. Water Res 39(17):4101-4109

van der Zee FP, Villaverde S, Garcia PA, Fdz-Polanco F (2007) Sulfide removal by moderate oxygenation of anaerobic sludge environments. Bioresour Technol 98:518-524

Van Haandel AC, Monroy O, Celis B, Rustrian E, Cervantes FJ (2006) Principles and process design for industrial wastewater treatment systems. In: Cervantes FJ, Pavlostathis SG, van Haandel AC (eds) Advanced biological treatment processes for industrial wastewaters - principles and applications. IWA Publishing, London, pp 118-132

Visser A, Hulshoff Pol LW, Lettinga G (1996) Competition of methanogenic and sulfidogenic bacteria. Water Sci Technol 33(3):99-110

Wang Z, Banks CJ (2006) Anaerobic digestion of a sulphaterich high-strength landfill leachate: the effect of differential dosing with $\mathrm{FeCl}_{3}$. Waste Manag Res 24:289-293

Wellinger A, Lindeberg A (eds) (1999) Biogas upgrading and utilization. Task 24: energy from biological conversion of organic wastes. IEA Bioenergy, Winterthur, pp 1-19

Yadav VK, Archer DB (1989) Sodium molybdate inhibits sulphate reduction in the anaerobic treatment of highsulphate molasses wastewater. Appl Microbiol Biotechnol 31(1):103-106

Zhang D, Verstraete W (2001) The anaerobic treatment of nitrite containing wastewater using an expanded granular sludge bed (EGSB) reactor. Environ Technol 22(8): 905-913

Zhou W, Imai T, Ukita M, Li F, Yuasa A (2007) Effect of limited aeration on the anaerobic treatment of evaporator condensate from a sulfite pulp mill. Chemosphere 66: 924-929

Zitomer DH, Shrout JD (2000) High-sulfate, high-chemical oxygen demand wastewater treatment using aerated methanogenic fluidised beds. Water Environ Res 72(1):90-97 